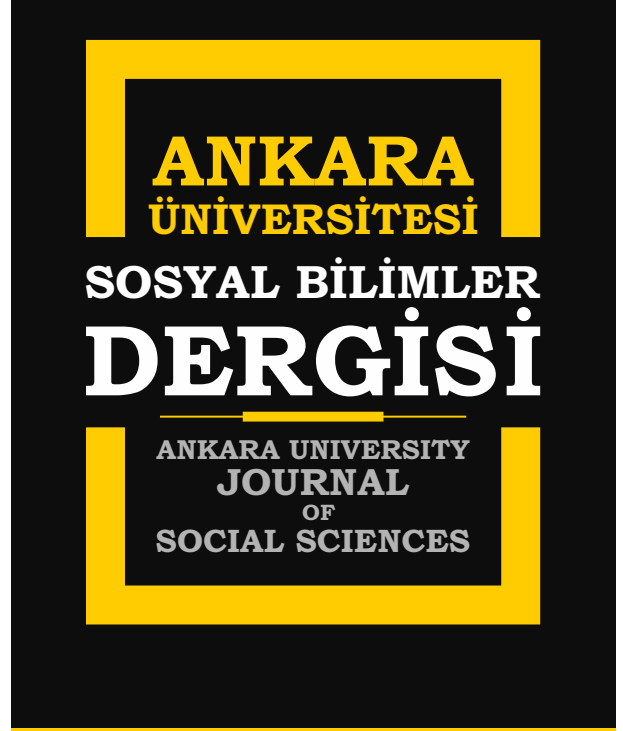

10.33537/sobild.2019.10.2.8

\section{Makale Bilgisi}

Gönderildiği tarih: Kabul edildiği tarih: Yayinlanma tarihi:

11-06-2018 27-06-2019 30.06.2019

Article Info

Date submitted: Date accepted:

Date published:

11-16-2018

27-06-2019

30.06.2019

\title{
LABOUR MARKET INTEGRATION of MIGRANTS in TURKEY \\ Weaknesses and Opportunities of Career Guidance for Migrants
}

\section{TÜRKIYYE'DE GÖÇMENLERIN ISSSGÜCÜ \\ PIYASASINA ENTEGRASYONU \\ Göçmenlere Yönelik Kariyer Danışmanlığ Hizmetlerinin \\ Zayıf Yönleri ve Firsatlar}

\section{Şenay GÖKBAYRAK}

Prof.Dr, Ankara Üniversitesi, Siyasal Bilgiler Fakültesi,

Çalışma Ekonomisi ve Endüstri İlişk. Bölümü,

gbayrak@politics.ankara.edu.tr

\section{Yelda DEVLET KARAPINAR}

Dr., Uluslararası Göç Örgütü Türkiye Misyonu, Kıdemli Uzman, ydevlet@iom.int

\section{Anahtar sözcükler}

Uluslararası Göç, Göçmen İşgücü, Kariyer Danışmanlığı, Türkiye.

\section{Keywords}

International Migration, Migrant Labour, Career Guidance, Turkey.
Öz

Bu çalışma, Türkiye'de göçmenlerin işgücü piyasasına entegrasyon sürecinde iş ve meslek danişmalarinın rollerini değerlendirmeyi amaçlamaktadır. Saha çalışmasının bulgular göçmenlerin nitelik ve becerilerine uygun işlere yerleştirilmelerine yönelik iş ve mesleki danışmanlik hizmetlerinin henüz gelişmediğini göstermektedir. Bu durum göçmenlere yönelik özel bir durum olmayıp, Türkiye'de iş ve meslek danışmanliğına yönelik hizmetlere ilişkin genel bir durumu ifade etmektedir. İk bakışta göçmenler kariyer danışmanlığına ilişkin hizmetler üzerinde bask yaratan bir yük olarak algılansa da; gerçekte işgücü göçü yönetiminde ortaya çıkan sorunların tartışılması ve çözümüne ilişkin önemli bir firsat yaratmaktadirlar.

\section{Abstract}

This study aims to access role of the job and vocational counsellors in the process of migrants' integration into the labour market in Turkey. The findings of our case study indicate that vocational consultancy services could not appear in terms of guiding migrants to jobs which are fit for their skills and qualifications. This is not a problem related to migrant but a general one. Although migrants are seen as a phenomenon increasing restrictions on career guidance at first sight; they actually create an opportunity to discuss and also solve such problems in the scope of labour and migration management. 


\section{INTRODUCTION}

Turkey appeared on the international migration scene as of the 1960 s as a source country of migration to Western European countries. This has largely changed since the 1990s with Turkey becoming a country of destination, initially due to transit migration, then because of labour migration. Asylum-seekers due to the civil war in Syria were added to these groups in recent years to an important extent. What migrants gravitating towards Turkey in different statuses have in common is that a considerable part of them work in the labour market throughout the time they remain in Turkey. Large-scale informal sector in Turkey provides the migrants with job opportunities. However, this leads to an increase in the presence of irregular migrant workforce in Turkey. In recent years, it has also been observed that irregular labour migration in Turkey is showing a tendency to become regular.

An increased labour migration due to recent economic, social, and political developments in Turkey also led to institutionalization of labour migration management as an emerging public policy framework. These developments paved the way for the integration of migrants into the labour markets as well as for increasing the discussion on creating mechanisms to facilitate these processes. Along with technical support by international organisations, efforts of relevant public institutions in Turkey to strengthen institutional and human capacity as a way to issue work permits for ensuring migrants' access to labour markets and to facilitate the integration were amplified. These efforts proved that job and vocational counsellors (JVCs) of Turkish Employment Agency (İSKUR) has a key role in supporting migrants' access to labour markets.

From this viewpoint, this paper aims to assess the role of JVCs in the process of migrants' integration into the labour market in Turkey. Migration types, migration and welfare policies, and labour market conditions in countries of destination have great influence in the migrants' integration into labour markets. This is why the first section of the study will look into the development dynamics of migratory movements in Turkey. The second section will analyse the migrants' position in the Turkish labour market as well as the developments taking place throughout the process from the viewpoint of regular and irregular migrant workforce individually. The third and the last section will discuss the role of JVCs in migrants' access to and integration in the labour market, opportunities and limitations surfacing within this process in the light of data from the qualitative field study.

\section{Historical Background of Labour Migration to Turkey: From Irregular Migration to Regular Migration}

\subsection{From Irregular Migration to Regular Migration Phase}

Increased migratory flows into Turkey are driven by economic and political crises and wars occurring in the neighbouring countries and in the region, Turkey's appeal in terms of its location as a transit country, Turkey becoming a country that is relatively easier to enter due to strict visa and migration policies implemented by the European countries, Turkey's better economic position compared to other countries in the region, and job opportunities that the informal labour market in Turkey offers to irregular migrants (Gençler, 2008; Erder, 2007; Toksöz, 2007; İçduygu, 2004; Gökbayrak and Erdoğdu; 2010; Toksöz et al., 2012; Fine, 2017).

It is possible to study the migratory movements into Turkey under four main groups: Asylum seekers and refugees (mainly from Middle Eastern countries like Syria, Iran, Iraq as well as various countries in Asia and in Africa); transit migrants (mainly from Middle-Eastern countries - Syria, Iran, Iraq; Asian countries - Pakistan, Bangladesh, Sri Lanka; African countries - Nigeria, Somalia, Republic of Congo); irregular migrants who are in Turkey to work (Bulgaria and Romania before their EU membership; Moldova, Ukraine, Russian Federation, Georgia, Azerbaijan, Armenia, Syria), and regular migrants with work permit (Georgia, Ukraine, Kirgizstan, Syria, Russian Federation, China) (MoFLSS, 2016). The ratio of regular migrants with work permit has risen in recent years; however, their share within the total migrant workforce is still relatively small. Whether transit or destination, what regular and irregular migrants have in common is that they work in the labour market throughout the time they spend in Turkey. However, the proportional weight of irregular migration within overall migratory process affecting Turkey results in migrants' working in the lowest layers of the informal labour market and under poor conditions, and the strategy of integrating into global markets based on cheap labour sustains the demand for irregular migrant labour (Gökbayrak and Erdoğdu, 2010).

Given the regular and irregular migrant distributions in Turkey over the years in Graph.1, the first point that stands out is the gradual rise of the number of regular migrants obtaining work permits. From this perspective, the increase in the number of 
migrants obtaining work permits in 2012 and 2013, in particular, is noteworthy. The main reason behind this increase is the regularisation carried out in 2012 under the coordination of Ministry of Family, Labour and Social Services (MoFLSS). This amnesty has resulted in the regularisation of the irregular female migrant labour which is especially common in domestic services such as child and elderly care by making it visible. As a matter of fact, in terms of nationalities of the migrants who have been obtaining work permits in recent years, top countries are Syria, Georgia, Ukraine, Turkmenistan, and Russia. Those who come from the top three countries are known to be migrant women employed predominantly in care and domestic services (Gökbayrak and Erdoğdu, 2010). Syrians obtaining work permits have been on the rise in recent years because Syrians were granted the right to work under their temporary protection status. In terms of the distribution of irregular migrants, irregular migration clearly preserves a larger share. The number of irregular migrants merely corresponds to the number of apprehensions, or in other words identified migrants. Taking into account the irregular migrants who were not apprehended, the number would clearly be far bigger.

\subsection{Syrian Refugees and Migration Management: From Crisis management to Migration Management}

Due to its location straddling two continents, Turkey has taken up a large number of asylum-seekers from countries in the Middle-East, Africa, Asia. The civil war that broke out in Syria in 2011 led Turkey to open its doors to Syrians, and today, Turkey is the country which hosts the biggest number of Syrian refugees worldwide. Turkey has signed the 1951 Refugee Convention with geographical limitation. This limitation is a geographical restriction, which means that only those who come from countries who are a member of European Council will be recognised as refugees. This is why Syrians are not defined as refugees but as foreigners that are granted temporary protection in Turkey. This legal status and the fact that only few Syrian refugees live in temporary accommodation centres and the vast majority are scattered in big cities as urban refugees lead to significant vulnerabilities in their economic and social lives. Although important humanitarian aid is provided to Syrian refugees in the field of healthcare and education within the available means, limitations on access to regular labour market

\section{Graph1. Distribution of Regular and Irregular Migrants during 2005-2015}

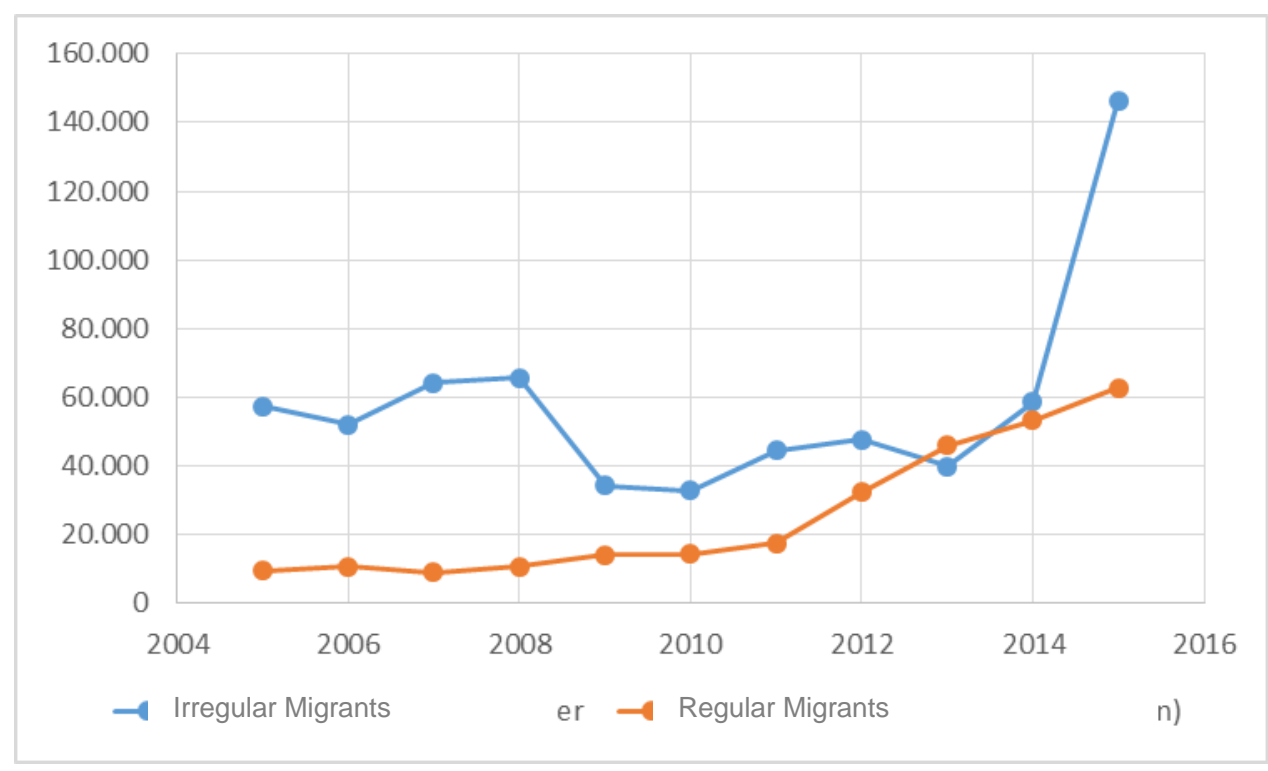

Source: Directorate General for Migration Management, Annual Migration Reports, 2013-2015.

In summary, there has been a momentum for the regularisation of labour migration in Turkey in recent years. Regularisation of labour migration resulted in a need to create a legal and administrative labour migration management process. Additionally, economic and social pressure resulting from the increasing refugee influxes due to the Syrian crisis have primarily been influential in acceleration of operational, normative and administrative efforts so as to manage international labour force. and adaptation to labour markets in cities persist despite the fact that Syrians under temporary protection have also been provided with the right to access to work permit. MoFLSS(2016) reports that Syrians are the top nationality among foreigners who were issued with work permits however, Syrians still end up in considerably insecure and low-paying jobs in the informal sector. Low income leads to a significant decrease in the quality of life, especially in terms of quality housing (Baban et al., 


\section{7; Del Carpio and Wagner, 2015)}

The significant rise in the number of Syrian refugees and surrounding issues motivated Turkey to accelerate its normative, operational and administrative framework pertaining to migration management, which dates back to early 2000s. Requirements of Turkey's EU accession, court cases opened against Turkey at European Court of Human Rights as well as changing migratory dynamics motivating Turkey's self consideration on the need to update its national normative framework on migration have all facilitated country to take progressive steps ahead. The Law on Foreigners and International Protection (LFIP) came into force in 2013 and the Directorate General on Migration Management (DGMM) in charge of the coordination of migration management issues with all relevant governmental entities was institutionalized. Syrian refugees were granted temporary protection in 2014 under the Regulation on Temporary Protection. The Regulation on Work Permits for Foreigners under Temporary Protection, issued in January 2016, gave the Syrians under temporary protection the right to work and to apply for work a permit. The Regulation on Work Permit for Foreigners under International Protection or Applicants of International Protection came into force in April 2016, regulated the right to work of persons under international protection as well as those recognised as conditional refugees.

On 13 August 2016, the Law on International Labour Force was ratified as the primary legislation aiming to identify, implement and monitor policies on international labour force as well as to regulate foreigners' work permit applications and labour market integration. The Law pursues two goals by promoting ways to attract qualified foreign labour by offering Turquois Card and facilitation of foreign university students' employment as well as countering irregular labour migration and exploitation of migrant workers. This legislative change has also called for the establishment of the Directorate General on International Labour (DGIL) under the MoFLSS as a central authority. Labour force management process has thus been given a holistic structure in both institutional and legal sense; transition from crisis management to migration management was ensured. However, it is the implementation of policies ensuring the access of migrant labour force to labour markets and their upward mobilisation that will determine the success of labour migration management over the next few years.

\section{Migrant Labour in Turkey}

\subsection{Irregular Migrant Labour}

Irregular trade relations (shuttle trade), which emerged in the aftermath of the disintegration of the former Soviet Union, played an important role in the rise of irregular labour migration in Turkey (Erder, 2007;
İçduygu, 2006). These trade relations were coupled with gradually increasing migration to Turkey from the region. When we take a look at the sectoral distribution of irregular migrants in the informal labour market, there seems to be a "division of labour" based on sectors and countries of origin of the migrant labour. 1 This division of labour is meaningful for existence of irregular migration both in terms of the demand for irregular migrants' labour and the influence of social networks. In Turkey, sectors where irregular migrant labour is concentrated include textile, agriculture, food production, construction, tourism, entertainment, and nursing (childcare, elderly care and patient care) sectors. The common denominator of these sectors is that these are the sectors where irregular and insecure work is also common for the local labour force (Gökbayrak and Erdoğdu, 2010). Given this aspect, irregular migrants evidently compete with local irregular workers and among themselves within the informal sector. Informal labour market has a layered structure with locals vs. migrants and per ethnicity and gender within the migrant group. Informal and unregistered employment in Turkey makes it possible for the irregular migrant labour to be absorbed (Toksöz, 2007; Gökbayrak and Erdoğdu, 2010; Toksöz et al., 2012; Del Carpio and Wagner, 2015; Ceritoğlu et al., 2017). The perception that the irregular migrant labour is "docile" because of lower wages, lack of social security rights, higher quality work combined with controllability increase their employability. The resulting invisibility in legal terms hampers the access of the irregular migrant labour to grieving and protection mechanisms, reproducing the already existing inequality and exploitation. This situation further heightens the existing segregation of formal/informal employment in labour markets on the one hand, while creating and heightening the segregation of locals vs. migrants within the informal sector as well as that of ethnicity and gender within migrant group on the other (Gökbayrak, 2009).

\subsection{Regular Migrant Labour}

Studies focusing on regular migration remained limited because migratory flows targeting Turkey predominantly comprise irregular migration. Nevertheless, an increase has been observed in the share of regular migrants with residence and work

\footnotetext{
${ }^{1}$ While those coming from Moldova concentrate in domestic care services, again people from Moldova as well as Russia, Romania and Ukraine are involved in entertainment sectors. There are workers from Moldova and Romania employed in the textiles sector whereas males from Iran, Iraq, Azerbaijan, Romania and Moldova work in constructions and from Ukraine, Pakistan, Romania and the Philippines in restaurants and food sector. Irregular migrant workers concentrate mostly in Marmara and Eastern Black Sea regions. In the former, the majör channels of employment include manufacturing industry and small and medium size enterprises in construction and services sectors and domestic services. In the latter they can be found as seasonal agricultural workers harvesting tea and hazel nut. They mostly work in tourism facilities and enterprises in the south (Erder, 2007; Toksöz,2007).
} 
permit within the total migrant labour over the last few years according to the MoFLSS data. A substantial portion of migrant labour, working under conditions (payment of wages, social security rights) that are not fully in line with the legislation despite holding the permit, should not be overlooked. The increase observed in the number of migrants with work permits in recent years was driven by the regularisation in 2012, LFIP regulations issued in 2013 to reduce the red tape in obtaining work permits, and by regulatory provisions allowing refugees and holders of secondary protection status to work dependently and independently.
Syria ranks first with 13290 people, and it is followed by Georgia with 7629 people, Ukraine (8668), China (4397), Kyrgyzstan (3048). It is a first for Syria to be the top country in that list, which results from the fact that those under temporary protection were granted the right to work in 2016. Considering the kinds of jobs held by those coming from countries of origin of irregular migration in particular, the sectoral distribution of regular migrants bears similarities with that of irregular migrants. More than 3.5 million migrants and refugees live in Turkey (majority of whom are Syrians under

Graph 2. Distribution of Work Permissions during 2005-2015

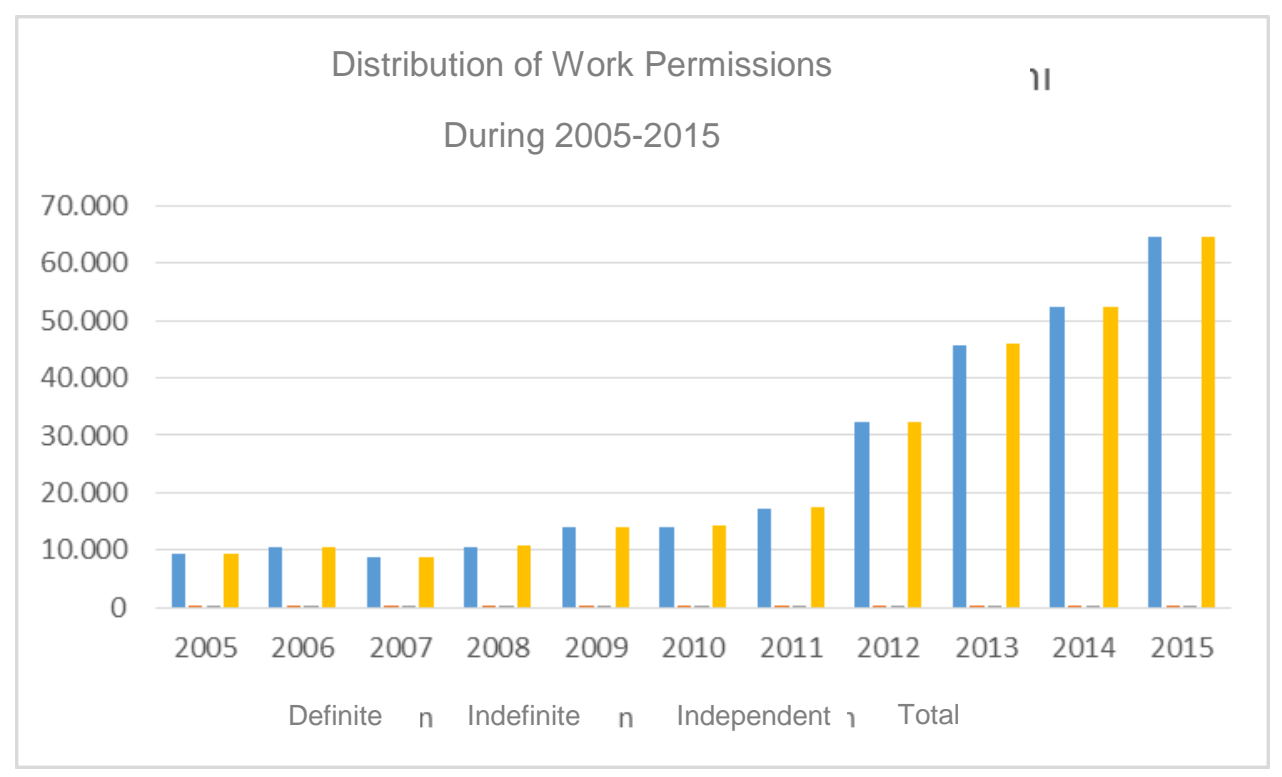

Source: MoFLSS, Collated from Reports on Work Permits of Foreigners, 2005- 2015.

A close look at the distributions given in Graph.2 reveals that the vast majority of work permits issued within the defined time period are temporary work permits. This is thought to be an indication of MoFLSS officials' cautionary attitude about issuing work permits in an environment where the unemployment and exploitation of migrant labour as cheap labour highly common (Toksöz et al., 2012). Additionally, the proportional weight of temporary work permits within all issued work permits indicate that there are very few migrants who meet the requirements to obtain a permanent work permit, which are a) having legally and continually resided in Turkey for at least eight years or b) having worked legally for a total of eight years. From this viewpoint, it is revealed that years of migration influxes into Turkey have just started to gain a regular character. It appears that almost the entire regular migrant labour force has the status of dependent worker in return for a service contract, and that there is barely any migrant labour force we can consider to be working independently on their account or an entrepreneur.

A look at countries of origin of regular migration into Turkey in terms of work permits issued in 2016 temporary protection) which calls for a comprehensive labour migration management strategy to help Turkey's economy to best utilize the influx of foreign labour. Looking at the sheer number it is evident that labour market inclusion of Syrians under temporary protection has become one of the defining issues of migration policy making in Turkey besides the ongoing humanitarian assistance programmes. MoFLSS reports that since the enactment of the Regulation on Work Permit of Foreigners under Temporary Protection in January 2016, the majority of the work permits issued for Syrians were for entrepreneurs and company shareholders.

An assessment of regular migrant labour distribution per gender reveals the phenomenon of feminisation of migration. Over the years, proportion of women in regular migration progressively increased to finally surpass men. The year 2012 stands out in terms of the rise in the number of migrant women obtaining work permits. The rapid increase in that year and the years that followed resulted from the regularisation put in place in 2012. The irregular female migrant labour 
appears to have been the ones mainly benefiting from the regularisation, switching to regular migrant status.

Graph 3. Distribution of Work Permissions According to the Gender during 2005-2015

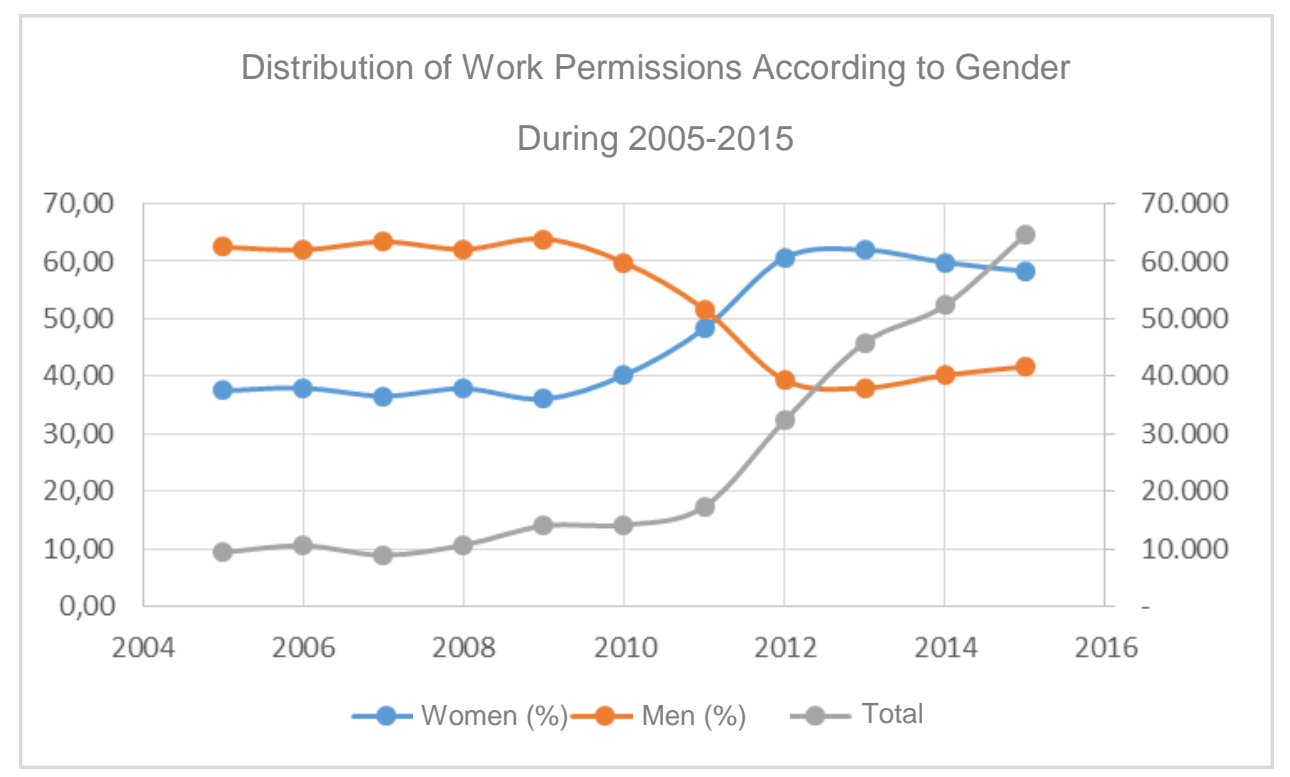

Source:, MoFLSS, Collated from Reports on Work Permits of Foreigners, 2005- 2015.

An assessment of the distribution of regular migrants per economic activity shows that nursing and domestic services, hospitality, creative arts, show and entertainment activities, wholesale trade and construction sectors are at the forefront (Gökbayrak ve Erdoğdu, 2010). The fact that irregular migrant labour is also substantial in the said sectors proves that irregular migrants are becoming regular within the process.

Age and education level are critical variables in ensuring access to labour markets and protection of skills for regular migrants. As far as age variable is concerned, young migrants have constituted the majority of those who obtained work permits over the years, and this trend has not changed. This is important in that it shows that migrants are part of the active population (aged 15-64) in terms of migrants' contribution to the economy; however, this contribution can only become manifest when they are employed in jobs in which they can fully utilise their qualifications. Thus, there is an important mass of migrants who are in need of an upward mobility in labour markets.

Graph 4. Distribution of Work Permissions According to the Age Groups during $2011 *-2015$

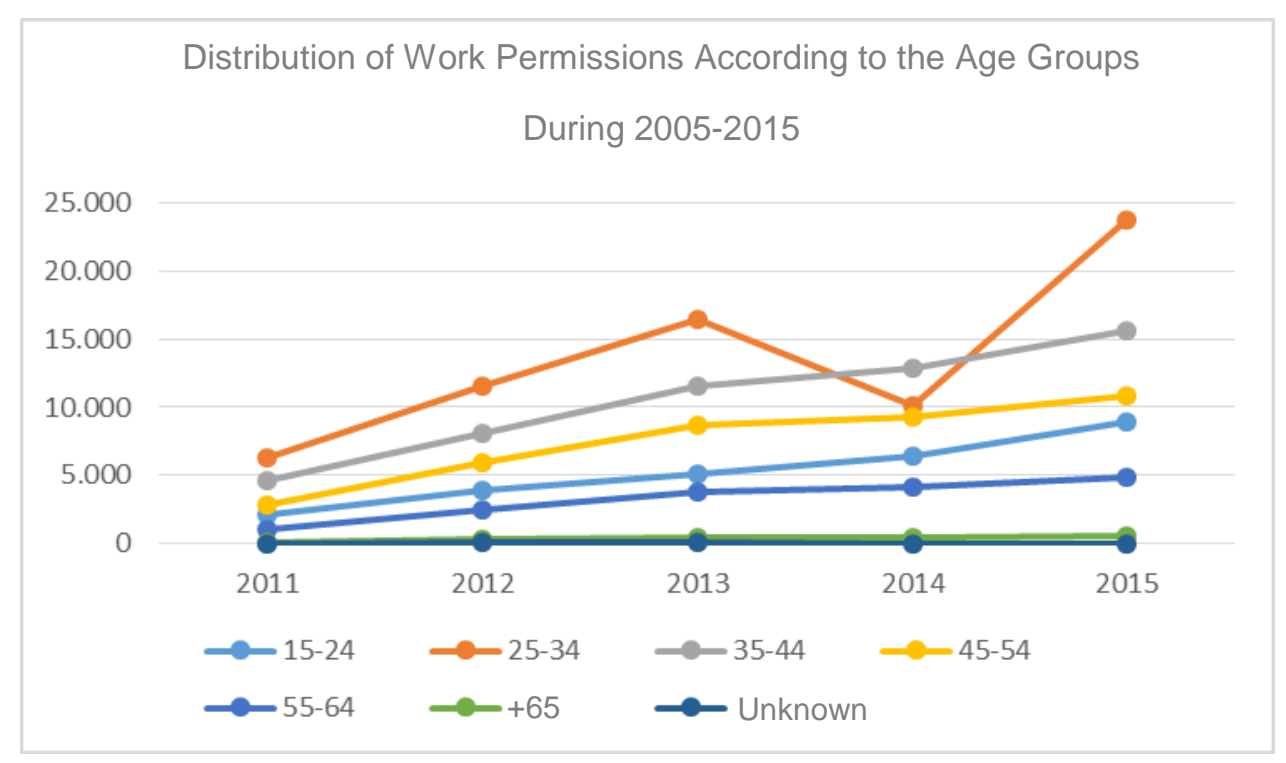

Source: MOFLSS, Collated from Reports on Work Permits of Foreigners, 2011-2015. 
* The year 2011 was used as baseline for the distribution because MoFLSS data showing age distribution of work permit holders has been published since 2011.

As for the distribution in terms of education level, which is the major determinant of the qualifications of regular migrant labour force, those with high school education and above are the majority (see Graph. 5). In recent years, the number of migrants with undergraduate and graduate degrees has been rising, which creates a significant potential to ensure the access to labour markets and upward mobility within labour markets for the migrant labour force. Yet, there has also been a rise in the share of people with no education and/or those with primary education over the last few years, which shows emergence of a potential obstacle before cohesion policies. Nevertheless, relatively lower proportion of those without any qualifications is relatively positive for potentially ensuring adaptation of migrants with work permits to the labour market.

Graph 5. Distribution of Work Permissions According to the Education Levels during 2011-2015

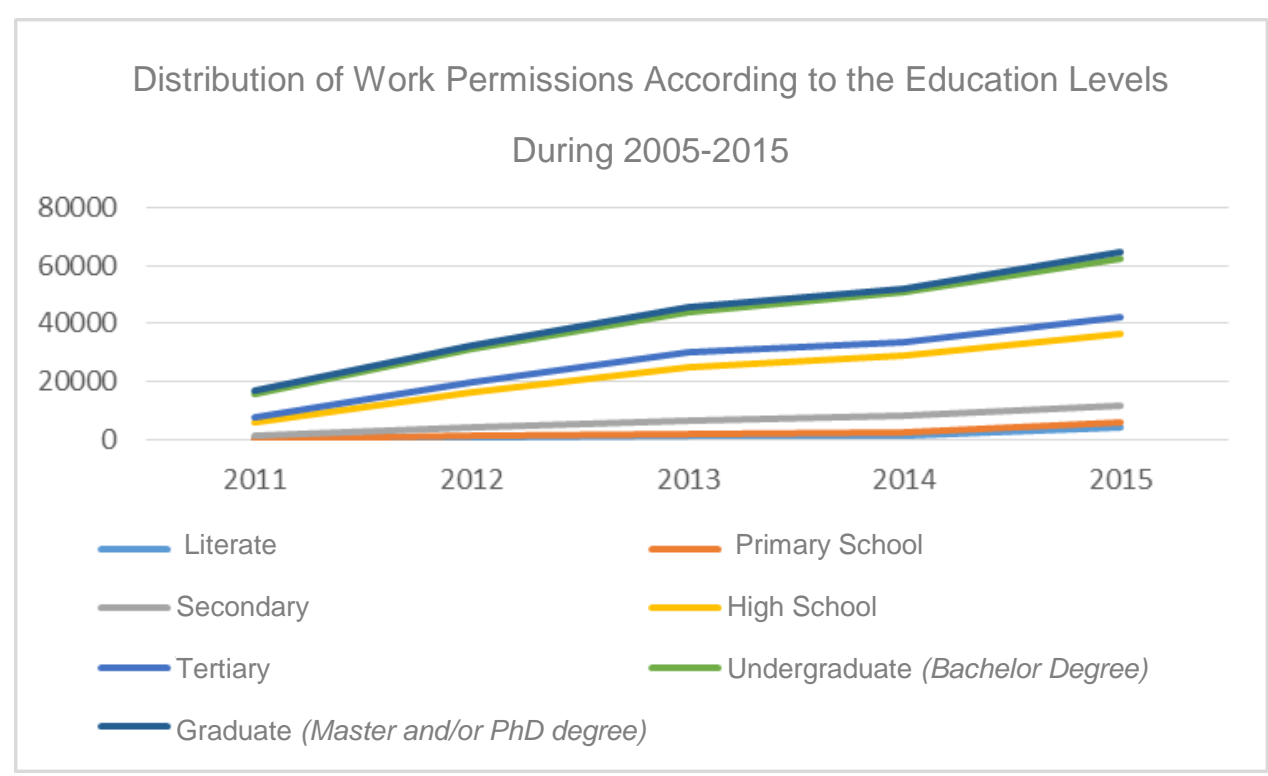

Source: MOFLSS, Collated from Reports on Work Permits of Foreigners, 2011-2015.

Graph 6. Distribution of Work Permissions According to the Education Levels and the Genger during 2011-2015

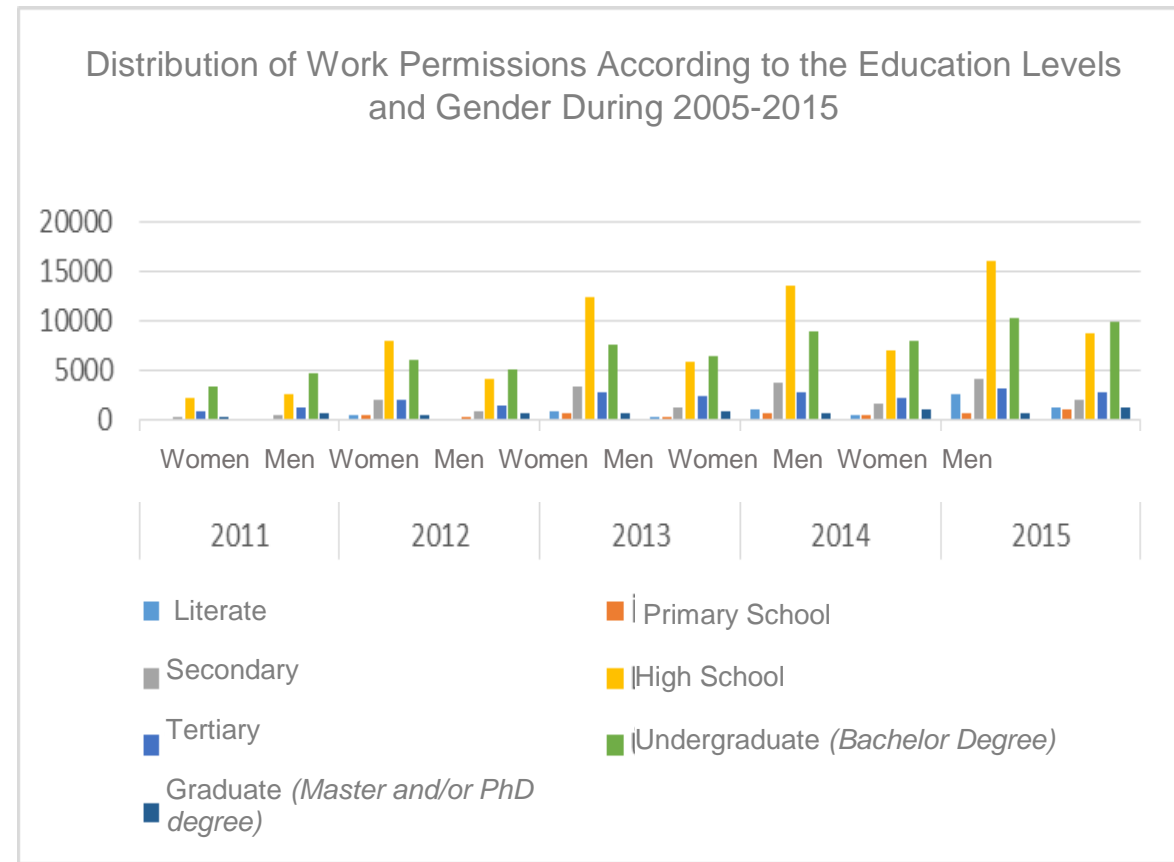

Source: MOFLSS, Collated from Reports on Work Permits of Foreigners, 2011-2015. 
As seen in Graph 6, education level of the female migrant labour force at all levels of education is strikingly higher than that of the male migrant labour force contrary to what would be expected. This is due to the increase in the number of female migrants following the amnesty granted to the irregular migrant labour force in 2012. A higher number of female migrants compared to men has also had an impact on the distribution of the education level of migrants in recent years. In 2011, when male migrant labour force was higher than female migrant labour force, male migrant labour force at all levels but particularly at university or higher levels of education outnumbered women.
Proportion of applications to extend the duration of work permits determines, in a way, the permanence of the migrant labour force. According to the International Labour Force Law, temporary work permit is issued for a duration of one year; and work permits may be extended following one year of legal working period for two years with the same employer upon the first application to extend, and for up to three years upon the following applications to extend. Applications with different employers are assessed in the scope of temporary (1-year) work permit application. Long-term residence permit holders and those who worked legally for eight years are entitled to the right to work for an indefinite period of time in Turkey.

\section{Graph 7. Distribution of Work Permissions According to the Extension Application during 2011-2015*}

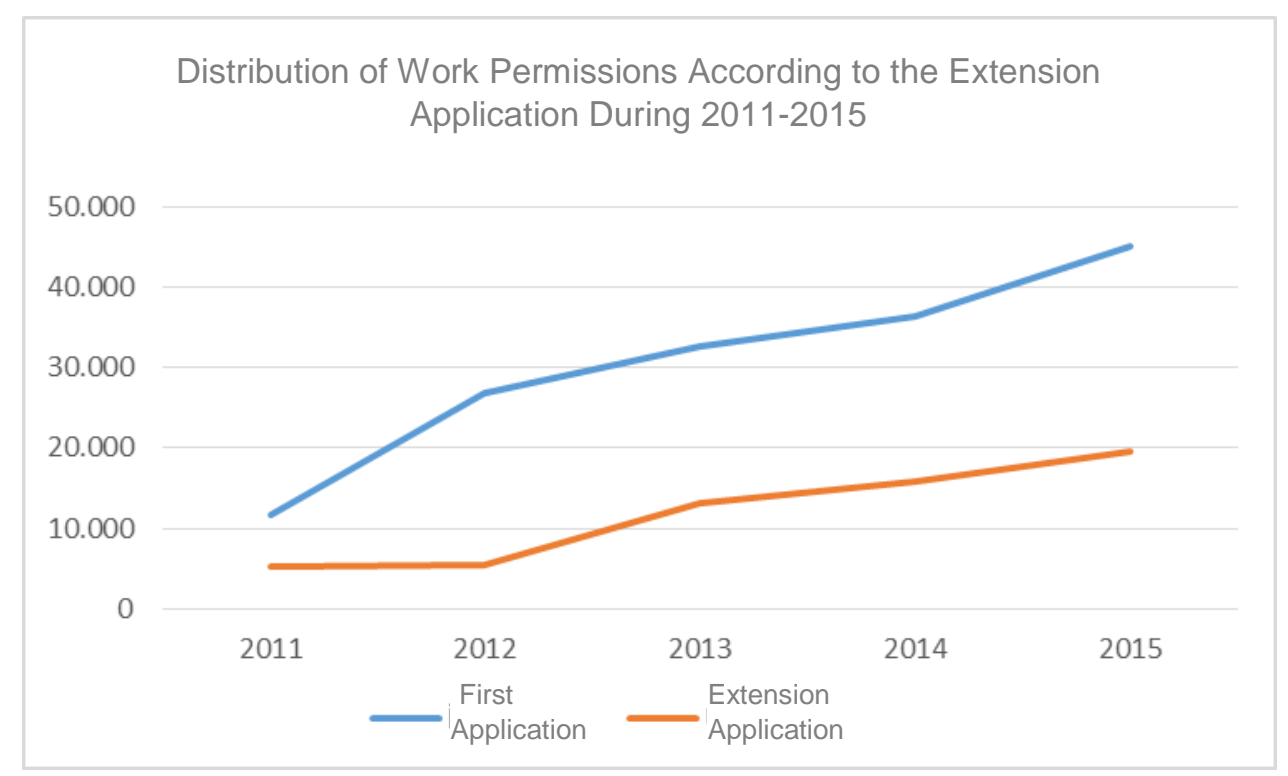

Source: MOFLSS, Collated from Reports on Work Permits of Foreigners, 2011-2015.

* The year 2011 was used as baseline for the distribution because MoFLSS data on extension applications of work permit holders has been published since 2011 .

Although a relatively higher level of education among the regular migrant labour force in general, and female migrant labour force in particular is a catalyst and overall positive for adaptation, a comparison between the jobs where migrants are concentrated, and their level of education reveal that they undergo skills erosion in the labour market. This situation is especially poignant for women employed in domestic care sector where migrant female labour force is concentrated. Given the lower level of education and skills of the local female labour force involved in domestic care services, relatively higher level of education and skills of the migrant female labour force is important; however, migrant women end up having to work at unqualified and low-paying jobs that are different from what they were trained for in most cases, in other words they get deskilled (Gökbayrak, 2009).
As seen in the Graph 7, a significant rise has been observed in the number of extension applications over the years. This shows that the phenomenon of labour force migration, which was temporary in the beginning, could become permanent in time to a significant degree. This goes to highlight the importance of and the need for strategy and policy sets to ensure adaptation of migrants to the labour market. Women's applications to extend work permits increased substantially over the years and surpasses those of men's in 2013. From 2011 to 2015, extension applications by women rose approximately six-fold while the increase in men's applications was around two-fold (MoFLSS, 2011-2015). The main concentration of the female migrant labour force in care services sector yet again shows how high the need for labour force in the care sector. These ratios prove that the migrant labour force will continue to be 
an important phenomenon in the labour market over the next years.

Similarities of working practices particularly in the irregular labour market between the migrant labour force and the local labour force further highlights the need to streamline the future policies to adapt the migrant labour force to the labour markets with the employment policies as a whole. Regularisation trend observed in labour force migration in the last few years emphasizes the supportive role of especially job and vocational consultants when it comes to ensuring the access of migrant labour force to labour markets as well as their upward mobility in labour markets.

III. Role of Vocational Consultancy in the Process of Adaptation to Labour Market: Limitations and Opportunities

\subsection{Integration of Migrants into Labour Markets and Career Consultancy}

The regularisation trend in the migrant labour force of Turkey over the last few years along with the high level of education of the migrant labour force makes it important to ensure migrants' access to labour markets without any loss of qualification. In the scope of general support programmes, consultancy, information, employment services as well as services on education, recognition of vocational training, qualifications and diplomas which support migrants' access to labour markets within the adaptation process come to the forefront (MIPEX, 2015).

Facilitation of access to public employment services for migrants and job search assistance services are among programmes implemented in many countries to reduce migrant unemployment (MIPEX, 2015). Assistance to job search refer to an intensive process of consultancy and assistance. Studies show that the likelihood of migrants finding jobs increase substantially when there is a strong coordination between central employment agencies and municipalities, especially the ones where migrants are concentrated (Bilgili, 2015). Public employment agencies should carry out regular analyses on sectoral labour force needs, regularly identify the need for migrant labour force as well as bring together the identified demand with the existing supply. An accurate match between the qualifications of migrants and labour market needs is critical to increase both migrants' adaptation to the labour market and positive externalities of migration for countries of destination; in other words, to reduce economic and social costs of migration. From this perspective, migrants' access to public employment services, improving their knowledge of labour markets, employment and vocational consultancy services tailored to migrants' needs, development of training and re-training services as well as employment services are main instruments of implementation.
Studies show that migrants have lower productivity even if they have the same qualifications as the local labour force, particularly in first years. This points to the existence of de facto discrimination even when there are anti-discrimination laws in place on the one hand and migrants' need for opportunities to improve their language skills, social capitals, and qualifications in the countries they reside on the other (Pina et al., 2015). Even when they are qualified, migrants lose skills in the context of jobs they have in the labour market especially in the first years of migration, and they try to overcome this challenge with their individual efforts by developing their social capital in the following periods (Gilmartin and Migge, 2015; Castagnone et al., 2015; Kogan, 2016). Especially due to different migration patterns, this is more amplified among refugees (Bevelander, 2016).

In this context, migrants' employment in labour market jobs that are suitable to their qualifications underline the importance of integration, increasing the productivity of the migrant labour force, and recognition processes for qualifications and skills of the migrants. Though development of diploma and qualifications recognition systems are underway in many countries, it is important to create recognition processes for diplomas and qualifications that are simple, central, readily accessible, and adapted to the specific needs of migrants as well as to build institutional capacity of countries in this respect (MIPEX, 2015)

Although it is important to place migrants in jobs that are suitable for their qualifications, it is not sufficient. Vocational training services and re-training services are crucial for acquirement of vocational qualifications suited to everchanging labour markets in that they facilitate adaptation by furthering migrants' qualifications and ensure their upward mobility in labour markets. Many countries provide vocational training programmes both in classrooms and in workplaces to improve migrants' vocational skills that suit the needs of the country they reside in (Aslund and Johansson, 2006; Thomsen et al., 2013; OECD, 2014; Takenoshito, 2014; Bilgili, 2015).

Job and vocational counsellors have a key role to play in ensuring access to labour markets for the migrant labour force, their placement in jobs suited to their qualifications, helping them benefit from vocational training and on the job training opportunities in line with sought-after skills in labour markets, and referring them to recognition mechanisms for their skills. Because, employment agencies are the public agencies migrants predominantly apply to in countries they reside. This is why strengthening the very recent role of theJVCs(JVCs) in labour market integration of migrants in Turkey is critical for successful labour migration management context. 


\subsection{Method}

This study is a exploratory research building on the findings of semi-structured interviews conducted with fifteen JVCs of Turkish Employment Agency (İSKUR) from the provinces of Gaziantep, Hatay, Kahramanmaraş, Urfa, İstanbul and Ankara which are the key refugee hosting provinces in Turkey. JVCs who participated in the research comprise 7 male and 8 female selected randomly. In-depth semi-structured interviews were held with the counsellors about their educational and professional backgrounds, their evaluations of their professions, impact of an increased labour migration on employment services.

\subsection{Findings}

\subsubsection{Education and Professional Experience of} JVCs : JVCs Unable to Practice Their Own Professions

Education level and professional education of JVCs are critical in terms of the value they add to what they do and their high labour productivity. However, JVC sare not working at a job that is suitable to their formal education. The profession of job and vocational consultancy was created in 2012 in Turkey. 4000JVCs (JVCs) were recruited throughout that year. This high number of recruitment in public employment services led many graduate teachers who were not appointed to apply for this job, which is considered a "secure and regular" job in the public sector. Of the career consultants we interviewed, all but three business management, engineering and public relations department graduates were teachers who graduated from Faculties of Education.

It is evident that they opted for job and vocational consultancy as a job because they had to, in a sense. They could not be appointed as teachers, previously worked as teachers in the private sector without security and under difficult conditions, which led them to switch to this profession considered a secure and regular job. Another key reason for female career consultants is the benefits afforded to women with young children in terms of the working hours and the stability of the public sector.

In terms of their professional experience, they have been working for the last six years. In a sense, job and vocational consultancy in Turkey is shaped through the way they practice the profession. Consequently, their professional evaluation of career consultancy proves critical even though their professional experience is relatively short.

\subsubsection{Job and Vocational Consultancy}

The audience served by JVCs within the mandate of the Turkish Employment Agency (İSKKUR) have diversity. They provide services to a large audience including employers, job-seekers, disadvantaged groups in terms of employment -women, youth, disabled, exconvicts and migrants due to recently increasing migratory influxes, trainees in the scope of job consultancy. They cite shortage of personnel as their major challenge as opposed to the broadness and diversity of the target audience and the quality of services provided. Shortage of JVCs is considered to be a limitation that increases the workload while reducing the quality of services.

The fact that their assignments have been broadened throughout the process despite the insufficient number of is perceived to be yet another limitation that lowered the service quality. Vagueness of their terms of reference and boundaries in this context leads to stress and unease among JVCs that they would continually be given additional tasks. The issue here is that efforts to place the unskilled unemployed persons with low employability potentials into jobs in a labour market where unemployment is structural and quite high results in both physical and mental weariness. see their capacity substantially pushed to its limits when they sometimes end up having to interview 100 people in one day and the audience they deal with have a low level of education. In the scope of the dynamics set in motion under the circumstances, shouldering new tasks, in other words, lack of boundaries in their terms of reference is perceived as a major limitation that impairs the quality of the job they do and drives them to desperation.

Lack of infrastructure, equipment and tools in the working environment of JVCs is also considered a major limitation in terms of their professional performance. Having three to four JVCs working together in relatively small offices is also identified as an element that lowers the service quality, which, after a while, leads them to trivialise the job they do.

Integration of both local and migrant labour force into the labour market under suitable conditions not only requires job placement but also, if not more, vocational consultancy. When assessed from this point view of JVCs end up having to focus more on job consultancy, or in other words, job placement rather than vocational counselling as they act in a local climate where unemployment is considerably high. This also results from the perception that ISKUR's only responsibility is being a job centre and the fact that almost all applications comprise job seekers .JVCs provide vocational consultancy services only to students whose education programmes are ongoing, that is upon request; however, these services have quite a limited share within their total workload. This is considered to be a limitation that causes JVCs to move away from the desired proactive approach that would prevent 
unemployment in particular and increase employability.

\subsubsection{JVCs in the face of Migrant Labour Force} on the Rise

The migratory impact of Syria Crisis has not only accelerated migration management efforts from central to local level but also paved the way for migration policy making at diverse thematic levels including labour migration, social policy, security, development, education and even foreign policy. Among all those verticals, labour migration management and labour market integration of foreigners with diverse status gradually emerged as one of the core denominators in overall migration agenda in Turkish context. Within this scope, essence of JVCs has been debated at an escalating pace as they are faced with the migrant labour force phenomenon under circumstances that are surrounded by structural issues. These structural issues and limitations they experience with their professions results in their not wanting to define themselves as responsible for ensuring migrants' access to labour markets in the first place. In provinces where the number of Syrian refugees is high, issues particularly of unemployment arising with migrants increase reactions towards Syrians, because Syrians are perceived to be the dependent population that exacerbates the unemployment among the local labour force. JVCs working in provinces with high number of Syrians mention that their workload has increased indirectly with the arrival of Syrians. It was not the Syrians themselves who increased their workload, but the local unemployed persons whose employability decreased because of the Syrians. Studies indicate that Syrians competed with and casted aside the local labour force with low employability potential within the informal sector because the former has quite low-level qualifications or no skills (Del Carpio and Wagner, 2015; Ceritoğlu, etc, 2017).Growing employment issues, caused by the Syrians, of the local labour force with already low employability potential have a negative impact on the way JVCs perceive Syrian refugees and the migrant labour force.

JVCs' perception of migrant labour force is shaped on the basis of the Syrian refugees. High numbers of Syrians and issues emerging in the social life result in the perception that labour migration equals Syrian migration. This also shows us that the JVCs have limited knowledge and awareness about labour migration and driving forces of migrant labour in Turkey. The fact that Turkey is now a country of destination for migration and that the migrant labour force will be an integral part of their target audience is not fully understood in the face of the structural circumstances of labour markets and local unemployment. This reality is best perceived by the JVCs who work in provinces where a high number of Syrians live.
From the perspective of JVCs who have previously worked with Syrians that were allowed to work under temporary protection, the major issue is language skills of migrants. Although ISKUR offers migrants employment services, vocational training and on-the-job training programmes in the scope of active labour market policies, the number of migrants applying to ISKUR in the first place is relatively low because of unregistered work of a substantial share of migrants. Language problems of the applicant migrants make employers not willing to employ migrants. This is defined as a major issue for the JVCs.

The fact that there are people who tend not to want to work due to concerns over losing the social benefits they receive, particularly among Syrian asylumseekers, does not lead the JVCs to perceive Syrians as a dependent, trouble-making audience. In an environment where local unemployment is high, this leads them to define Syrians as a balls-up adding to their workload both directly and indirectly.

All of these circumstances lead JVCs to not be able to fully perform their function as vocational consultants, which is crucial for migrants' integration into labour markets. As mentioned earlier in the paper, even though vocational consultancy services for the migrant labour force are considered essential, it is not known how they will be actually be delivered in practice by JVCs who already have to tackle job consultancy services in an environment where unemployment is quite high.

The fact that JVCs have improved their skills of awareness and empathy as a result of trainings that they have undergone despite all these restrictions is an indication of the crisis having some opportunities to manage labour migration regardless of restrictions which increased following the refugee crisis.

\section{CONCLUSION}

Today's Turkey can be categorized as a country of destination, transit, origin as well as a first country of de facto asylum. Although a significant part of migrants consisted of irregular migrants, it has been witnessed in the recent years that the number of migrants who are employed in Turkey has also increased in the scope of regular migration. Even though the increase in the number of regular migrant labour force is a positive development, it is a known fact that migrants are not always employed in line with legal requirements as far as their labour and social security rights in the labour market are concerned. Therefore, institutional support mechanisms which may ensure migrants' regular access to labour market are significantly important. It is important to have regular access to labour market, 
although it is not sufficient alone. It is also important to create opportunities which would ensure full access to labour rights as granted in the international and national obligations. Adaptation strategies and policies which would be developed to ensure upward mobility in the labour market through migrants' access to labour market appear to be an important requirement for Turkey to create positive externalities both for migrants and as a country which receives migration.

Experience that various countries have underlines the importance of career guidance services to increase both migrants' access to labour markets and their upward mobility in labour markets. Therefore, the importance of integrating migrant labour force into labour markets which has increased after the migratory impact of Syria Crisis creates a need for using the capacity of JVCs in this regard. The training and professional experience that JVCs have, the working conditions as well as the pressure created by migrants in the labour market upon groups whose employability is problematic all create serious restrictions when the role that JVCs play to ensure migrants' integration into labour market is tried to be increased.

When such restrictions are analysed in detail, those that are caused by JVCs and affect migrant labour force are obviously caused by inadequate capacity which is not only related to migrant labour force but also to structural problems of the labour market as a whole. JVCs often provide consultancy for being placed in a job when unemployment is already high, they cannot provide vocational consultancy in such a setting. Therefore, the fact that vocational consultancy services could not appear in terms of guiding migrants to jobs which are fit for their skills and qualifications is not a problem related to migrant but a general one. Although migrants are seen as a phenomenon increasing restrictions at first sight and making it harder to identify such structural problems and develop solutions for them, they actually create an opportunity to discuss such problems.

The existence of structural problems concerning employment in Turkey has become more controversial in the context of labour migration due to the pressure created by the migratory impact of Syria Crisis. This crisis has paved the way for the emergence of labour migration management process which has shown relatively slow progress for many years. Unemployment, informal employment and social aid are currently discussed with a focus on migrants. But such issues have actually been discussed in Turkey for a long time. The first results of capacity building activities which became part of agenda focusing on integrating migrant labour force show us that migrants can actually become an opportunity to strengthen institutional capacity in terms of employment and social policies in Turkey. As seen in working practices of JVCs, vocational consultancy programmes focusing on migrants create opportunities not only for migrants but for policy makers as well to develop vocational consultancy services as a whole.

Creating an opportunity out of the employment crisis caused by migrant labour force necessitates creating and implementing general employment policies for international labour migrants as well as mainstreaming such policies into monitoring processes. Ensuring that both Turkey and migrant labour force obtains positive externalities out of international labour migration in the scope of "win-win" principle depends on mainstreaming labour migration into employment and labour force policies particularly focusing on adaptation to labour markets and ensuring the sustainability of all activities conducted by all relevant stakeholders to increase the adaptation capacity of the community to international labour migration and that of migrants.

\section{REFERENCES}

Åslund, O., Johansson. P.(2006). "Virtues of SIN-Effects of an Immigrant Workplace Introduction Program." Working Paper 7, IFAU.

Baban, F; Suzan Ilcan \& Kim Rygiel (2017) Syrian refugees in Turkey: pathways to precarity, differential inclusion, and negotiated citizenship rights, Journal of Ethnic and Migration Studies, 43:1, 41-57, DOI: 10.1080/1369183X.2016.1192996.

Bevelander,P. (2016), "Integrating refugees into labor markets: Economic integration of refugees into their host country is important and benefits both parties", IZA World of Labor 2016: 269: 1-9.

Bilgili, Ö. (2015), Evaluating Impact: Lessons Learned form Robust Evaluations of Lbaour Market Integration Policies,

http://mipex.eu/sites/default/files/downloads/files/mi pex_evaluating-impact-lessons-learned-from-robustevaluations-of-labour-market-integration-policies.pdf

Castagnone, E.; Nazio, T.; Alberto, C.C.; Bartolini, L; Schoumaker, B., (2015), "Understanding Transnational Labour Market Trajectories of African-European Migrants: Evidence from the MAFE Survey”, International Migration Review,49(1): 200-231.

Ceritoglu, E., H. Burcu Gurcihan Yunculer Huzeyfe Torun and Semih Tumen (2017), "The impact of Syrian refugees on natives' labor market outcomes in Turkey: evidence from a quasi-experimental design", IZA Journal of Labor Policy, 6(5): DOI 10.1186/s40173-017-0082-4.

Claudia Finotelli \& Irene Ponzo (2017), “ Integration in times of economic decline. Migrant inclusion in Southern European societies: trends and theoretical implications," Journal of Ethnic and Migration Studies, 
DOI: $10.1080 / 1369183 X .2017 .1345830$.

MOFLSS, (2016), 2016 Work Permits of Foreigners Ankara.

MOFLSS,,2009-2015 Reports on Work Permits of Foreigners, Ankara.

Del Carpio, Ximena V. and Wagner, M. (2015), The Impact of Syrian Refugees on the Turkish Labor Market, World Bank Policy Research Working Paper 7402.

Erder, S.(2007), “ Foreigners in Turkey constructed without foreigners", in Foreign Workers in Turkey: International Migration, Labour and Population Movements (ed: Aylan Ar1) Derin Yayınlar1, İstanbul: 182. (in Turkish)

Fine, Shoshana (2017): Liaisons, labelling and laws: International Organization for Migration bordercratic interventions in Turkey, Journal of Ethnic and Migration Studies, DOI:

\subsection{0/1369183X.2017.1354073}

Gençler, A.(2008), “ Labour Globalization with informalization : Illegal Labour Migration in Turkey", in Is the Turkish Labour class and movement globalizing ?Publication of Foundation of Social Research and Center of Class Research in Turkey, İstanbul: 25-50. (in Turkish).

Gilmartin,M; Migge, B. (2015), "European migrants in Ireland: Pathways to integration", European Urban and Regional Studies, 22(3): 285-299.

Gökbayrak, Ş ; Erdoğdu, S. (2010), "Irregular Migration and Trade Union Responses: The Case Of Turkey", "İş, Güç" Endüstri İişkileri ve İnsan Kaynakları Dergisi, 12(2): 89-114.

Gökbayrak, Ş. (2009), "Welfare State Transformation and Women Migrants as a Indivisible Care Workers", Labour and Society, 21(2): 55-81. (in Turkish).

İçduygu, A.(2004), Irregular Migration to Turkey, Publication of Istanbul Chamber of Commerce, No:200465, Istanbul (in Turkish).

Kogan, I. (2016), "Integration Policies and Immigrants' Labor Market Outcomes in Europe.", Sociological Science, 3: 335-358.

MIPEX (2015), Migration Integration Policy Index 2015, http://www.mipex.eu/

OECD (2014), Matching economic migration with labour market needs in Europe, OECD/European Union.

Pina, A.; Corluy, V.; Verbist, G. (2015), Improving The Labour Market Integration of Immigrants in Belgium, OECD Economics Department Working Papers No. 1195.
Takenoshito, H. (2014), "Labor market structure, welfare policy and the integration of immigrants in Japan: Brazilian immigrants during the economic downturn", Malmo Institute for Studies of Migration, Diversity and Welfare, in Malmo University on September 24th, 2014.https://www.mah.se/upload/Forskningscentrum /MIM/2014\%20Seminars/140924\%20Takenoshita\%20 Malmo\%20paper.pdf

Thomsen, S.,. Walter,T; Aldashev, A. ( 2013). "ShortTerm Training Programs for Immigrants in the German Welfare System: Do Effects Differ from Natives and Why?" IZA Journal of Migration 2:24.

Toksöz, G. (2007), "Informal Labour Markets and The Need for Migrant Workers: The Case of Turkey from Comparative Perspective", Irregular Migration, Informal Labour and Community: a Challenge for Europe, (eds: Erik Berggren, Branka Likic- Brboric, Gülay Toksöz ve Nicos Trimikliniotis), Shaker Publishing: 183-198.

Toksöz, G; Erdoğdu, S; Kaşka, S. (2012), Irregular Labour Migration and Irregular Migrant Labour in Turkish Labour Market IOM. (in Turkish) 